\title{
Axons Regulate the Distribution of Schwann Cell Microtubules
}

\author{
Grahame Kidd, ${ }^{3}$ S. Brian Andrews, ${ }^{2}$ and Bruce D. Trapp ${ }^{1}$ \\ 1 Department of Neurosciences, The Cleveland Clinic Foundation, Cleveland, Ohio 44195, 2Laboratory of Neurobiology, \\ National institute of Neurological Disorders and Stroke, National Institutes of Health, Bethesda, Maryland 20892, and \\ ${ }^{3}$ Department of Neurology, The Johns Hopkins University School of Medicine, Baltimore, Maryland 21287
}

It is well established that axons regulate Schwann cell phenotype. The purpose of the present study was to determine whether axons influence the arrangement of Schwann cell microtubules (MTs). Using double-labeling immunocytochemistry and confocal microscopy, we show that MTs in undifferentiated Schwann cells are nucleated from and attached to a single MT organizing center (MTOC) that is associated with the centrosome. Physical contact with appropriate axons initiates a myelin-forming phenotype that disperses MT minus ends and induces multiple MT-nucleating sites in Schwann cell perinuclear cytoplasm. The axonal signal that initiates myelin breakdown during Wallerian degeneration induces multiple MTOCs and MT bundles in Schwann cell perinuclear cytoplasm and in cytoplasm between degenerating myelin ovoids. These results establish that axons influence Schwann cell MT distribution by regulating the location and number of MT-nucleation sites.

Key words: axonal signaling; microtubules; MTOC; myelination; Schwann cell; Wallerian degeneration
Differentiation of polarized epithelial cells is a complex process that involves expression of specific gene products, repression of previously active genes, polarization of cytoskeletal networks, and development of specialized intracellular transport pathways. This process has been well studied in epithelial cells, where cell-cell contact initiates the production of specialized apical and basolateral surfaces (Rodriguez-Boulan and Nelson, 1989; Simons and Wandinger-Ness, 1990; Mostov et al., 1992). A key event in epithelial cell differentiation is the transformation of the microtubule (MT) network from one that radiates from the centrosome to a network that originates primarily from multiple points close to the apical surface (Bre et al., 1987, 1990). This establishes a polarized network of MTs that have their minus ends at the apical surface and plus ends oriented toward the basal membrane, providing specialized transport pathways for protein targeting (Bre et al., 1987; Hugon et al., 1987; Achler et al., 1989). Via interactions with MTs (Thyberg and Moskalewski, 1985; Matteoni and Kreis, 1987; Kreis, 1990), the distributions of the Golgi apparatus endoplasmic reticulum, intermediate filaments, and endosomes also become polarized (Bre et al., 1987; Parton et al., 1991).

Schwann cells, the myelin-forming cell of peripheral nerves, are epithelial cells that display different phenotypes that are dependent of axonal interactions (Aguayo et al., 1976; Weinberg and Spencer, 1976; Spencer et al., 1981). Different Schwann cell phenotypes are caused by no axonal contact, contact with multiple small axons, contact with a single large axon, or contact with

Received June 30, 1995; revised Oct. 3, 1995; accepted Nov. 1, 1995

This work was supported by Grants NS22849 and NS29818 from the National Institute of Neurological Disorders and Stroke. G.K. was supported by a postdoctoral fellowship from the National Multiple Sclerosis Society. We thank Drs. Don Cleve land. Doug Murphy, and Pamela Talalay for helpful comments and Lois Becker for typing and editing this manuscript. We also thank Diana Curley for technical assistance and Drs. Lynn Rutkowski and Ted George for providing Schwann cell cultures.

Correspondence should be addressed to Dr. Bruce D. Trapp, Department of Neurosciences, NC30, The Cleveland Clinic Foundation, 9500 Euclid Avenuc, Cleveland, $\mathrm{OH} 44195$.

Dr. Kidd's present address: Department of Biochemistry, The University of Queensland. St. Lucia, 4072 QLD, Australia.

Copyright $\mathrm{O} 1996$ Society for Neuroscience $\quad 0270-6474 / 96 / 160946-\bullet 05.00 / 0$ degenerating axons. Schwann cell phenotypes are characterized by distinct morphologies (Peters et al., 1991; Thomas et al., 1993) and the differential expression of myelin proteins, cell adhesion molecules, receptors, enzymes, intermediate filament proteins, ion channels, and extracellular matrix proteins (Mirsky et al., 1980; Bunge et al., 1982; Politis et al., 1982; Winter et al., 1982; Poduslo et al., 1984; Trapp et al., 1988; Yao et al., 1990; Mezei, 1993).

Schwann cells isolated from neonatal nerve and grown in vitro without axons are small bipolar cells that express nerve growth factor receptor (NGF-R) (Yasuda and Dyck, 1987), neuronal cell adhesion molecule (NCAM), and L1 (Seilheimer and Schachner, 1987), but not myelin proteins (Winter et al., 1982) or a basal lamina (Bunge et al., 1982). Schwann cells that contact axons in vivo downregulate NGF-R (Taniuchi et al., 1986; Lemke and Chao, 1988) and assemble a basal lamina (Bunge et al., 1982). Some Schwann cells ensheathe multiple small axons and form the unmyelinated fibers of mature nerves (Peters et al., 1991; Thomas et al., 1993). These Schwann cells express glial fibrillary acidic protein (GFAP) (Jessen and Mirsky, 1984), NCAM, L1 (Martini and Schachner, 1986; Jessen et al., 1987), and $\mathrm{Na}^{+} / \mathrm{K}^{+}$-ATPase (Ariyasu and Ellisman, 1987). Other Schwann cells myelinate single axons, express the myelin proteins $\mathrm{P}_{0}$, myelin basic protein (MBP), $\mathrm{P}_{2}$, myelin-associated glycoprotein (MAG), and PMP-22 (Trapp et al., 1981; Martini and Schachner, 1986; Lemke and Chao, 1988; Trapp et al., 1988; Yao et al., 1990) and downregulate NCAM, L1, and GFAP (Martini and Schachner, 1986). When axons of myelinated fibers degenerate, myelin internodes undergo a progression of autolysis in which the compact myelin pinches off into successively smaller ovoids and is degraded (Stoll et al., 1989; Griffin and Hoffman, 1992). As Wallerian degeneration proceeds, the Schwann cell downregulates myelin protein gene expression (Lemke and Chao, 1988; Trapp et al., 1988; Leblanc and Poduslo, 1990) and produces NGF-R (Taniuchi et al., 1986; Lemke and Chao, 1988), NCAM, and L1 (Jcssen ct al., 1987).

Because axons cause dramatic changes in Schwann cell size, shape, and membrane organization, it is reasonable to expect that 
different Schwann cell phenotypes have specialized MT networks. To test this hypothesis, the present study compared the organization of MTs in Schwann cells without axonal contact, in myelinating Schwann cells and in degenerating myelin internodes after nerve transection. The results of this study establish that axons dynamically regulate $\mathrm{M}$ l' organization in myelinating Schwann cells.

\section{MATERIALS AND METHODS}

Normal rat sciatic nerve. Male 35-d-old Sprague-Dawley rats were anesthetized and perfused intracardially with $4 \% p$-formaldehyde and $0.08 \mathrm{M}$ Sorrenson's phosphate buffer. The sciatic nerves were removed and cut into $2 \mathrm{~mm}$ segments. Nerve fibers were teased from these segments, immunostained, and analyzed by confocal microscopy.

Colchicine treatment. Ten 35-d-old Sprague-Dawley rats were anesthetized, and their right sciatic nerves were exposed. A $2 \mathrm{mg}$ swab of rayon wool soaked with $20 \mu \mathrm{l}$ of $5 \mathrm{~mm}$ colchicine (Sigma, St. Louis, MO) was wrapped around the nerve. A strip of Parafilm then was slipped carefully around the nerve and cuff to limit colchicine exposure to overlying tissues After $2 \mathrm{hr}$, the cuff was removed and the animal was allowed to recover. In five animals, the sciatic nerve was transected immediately after cuff removal. At $12 \mathrm{hr}$ and at 1, 2, 3, and $4 \mathrm{~d}$ after colchicine cuff removal, the rats were perfused with $4 \% p$-formaldehyde and $0.08 \mathrm{M}$ phosphate buffer. The nerve segments covered by the cuff were removed. Nerve fibers were teased from these segments, immunostained, and analyzed by confocal microscopy.

Nocodazole treatment. Sciatic nerves from four 35-d-old C57B1/6 mice and eight Sprague-Dawley rats were removed under anesthesia, cut into $6-8 \mathrm{~mm}$ segments, transferred to culture medium containing $10 \%$ fetal calf serum (FCS) and $6000 \mathrm{mg} / \mathrm{l} \mathrm{D}$-glucose in DMEM (Gibco, Gaithersburg, MD), and incubated at $38^{\circ} \mathrm{C}$ in $5 \% \mathrm{CO}_{2}$. Nocodazole (Sigma) was dissolved in dimethylsulfoxide (DMSO) and added to the culture medium to give a final concentration of $100 \mathrm{~mm}$ nocodazole and $0.2 \%$ DMSO. Nerve segments were cultured for $18 \mathrm{hr}$ in nocodazole-containing culture medium. They were rinsed and transferred to nocodazole-free culture medium for 6,30 , or $56 \mathrm{hr}(24,48$, and $72 \mathrm{hr}$ in vitro $)$. Nerves were fixed for immunostaining in phosphate-buffered $4 \% p$-formaldehyde that was prewarmed to $38^{\circ} \mathrm{C}$. Four nerve segments were allowed to degenerate in culture without nocodazole for 24,48 , and $72 \mathrm{hr}$.

Schwann cells in vitro. In four experiments, dorsal root ganglia were removed from newborn rats, plated onto six collagen-coated glass coverslips, and maintained at $38^{\circ} \mathrm{C}$ for $5-7 \mathrm{~d}$ in DMEM containing $10 \% \mathrm{FCS}$. In two experiments, primary cultures of adult rat Schwann cells were obtained by collagenase treatment of sciatic nerve segments. Cells then were plated onto collagen-coated coverslips in DMEM containing $10 \%$ FCS. Passaged neonatal Schwann cells were obtained from neonatal rat sciatic nerves as described above and were stimulated to divide by treatment with cholera toxin (Rutkowski et al., 1990). Passaged cells examined in these studies were expanded seven times. All cells were maintained at $37^{\circ} \mathrm{C}$ in a $5 \% \mathrm{CO}_{2}$ atmosphere.

Cultured cells on coverslips were pretreated with $1 \%$ Triton $\mathrm{X}-100,5$ mM 1,4-piperazinediethanesulfonic acid, and 2 mM EGTA for 1 min at $22^{\circ} \mathrm{C}$ and then plunged into $-20^{\circ} \mathrm{C}$ methanol for $5 \mathrm{~min}$. The cells were warmed to $22^{\circ} \mathrm{C}$ and transferred to PBS before immunostaining. Some coverslips were fixed with $4 \% \mathrm{p}$-formaldehyde in $0.08 \mathrm{M}$ Sorensen's phosphate buffer for 2 hr at $38^{\circ} \mathrm{C}$.

Immunofluorescence staining. Bundles of several hundred nerve fibers were teased, permeabilized in Triton X-100 for $2 \mathrm{hr}$, washed in PBS, and double labeled. Nerve fibers were incubated with primary antibodies for $18 \mathrm{hr}$ at $4^{\circ} \mathrm{C}$, washed, and then incubated in affinity-purified fluoresceinand Texas red-conjugated secondary antibodies (Amersham, Arlington Heights, IL) for $2 \mathrm{hr}$ at $22^{\circ} \mathrm{C}$. Tissues were washed in PBS and placed on slides in a Mowiol-based medium (Calbiochem, San Diego, CA) containing $0.1 \% p$-phenylene diamine. Specificity of the immunostaining was tested by omitting primary and/or secondary antibodies. To compare staining patterns of Schwann cells with those in fibroblast and perineurial cells, epineurial and perineurial connective tissue layers were stripped from the nerve segments, immunostained, and mounted flat on microscope slides. The primary antibodies used are well characterized and include mouse monoclonal antibodies specific for acetylated $\alpha$-tubulin (Piperno et al., 1987) and rabbit polyclonal antibodies specific for $P_{*}$ protein (Trapp et al., 1981), pericentrin (Doxsey et al., 1994), and S100 (Dako, Carpenteria, CA). Nuclear and chromosomal DNA were imaged using propidium iodide (Molecular Probes, Eugene, OR). In each teased fiber preparation, at least 100 immunostained Schwann cells were examined. Two or more coverslips of cultured Schwann cells were immunostained in each experiment; at least 50 Schwann cells per coverslip were examined.

Confocal microscopy. Confocal microscopy was performed using a Bio-Rad Lasersharp MRC 600 System (Hercules, CA) and a Leica Aristoplan confocal laser-scanning microscope (Nussloch, Germany). Confocal images representing optical sections of $\sim 1 \mu \mathrm{m}$ axial resolution were collected. Final images represented the average of $8-10$ frame scans of the chosen field (Kalman frame averaging, Bio-Rad) or 32 line scans (Leica). In some cases, a 2- to 3- $\mu$ m-thick optical section ("throughfocus" image) was generated by combining two or three consecutive images from a $z$-series. Degenerating myelin internodes also were imaged using a transmitted-light detector. This produced an interferencecontrast-like image of the entire internode thickness, rather than a confocal optical section.

\section{RESULTS}

\section{Organization of MTs in Schwann cells maintained in the absence of axonal contact}

In these studies, MTs were localized with acetylated $\alpha$-tubulin antibody. Because this antibody recognizes polymerized MTs (Piperno and Fuller, 1985; Piperno et al., 1987) and does not react with the soluble pool of monomeric $\alpha$-tubulin, clear images of Schwann cell MTs can be obtained without the substantial competing staining of the cytoplasmic tubulin pool. To investigate the organization of MTs in Schwann cells that were not associated with axons, Schwann cells maintained in vitro were immunolabeled with antibodies directed against tubulin and Schwann cell antigens and were examined by confocal microsenpy. Dorsal root ganglion cultures from neonatal rats were used because they contained Schwann cells that have not myelinated. In these primary cultures, many Schwann cells had migrated away from the ganglion and were not associated with axons that are recognized by intense MT staining. Schwann cells were identified by their symmetric bipolar morphology and S100 immunostaining. Staining for acetylated $\alpha$-tubulin indicated that in all of the Schwann cells $(>200)$ migrating away from dorsal root ganglion, MTs diverged from a single site containing the pericentrin-positive dot that represents the centrosome (Figs. $1 A-D$ ). The centrosome was always located near the nucleus in these cells (Fig. $1 C, D$ ).

A different MT organization was observed in Schwann cells obtained from primary cultures of adult rat sciatic nerve (Fig. $1 E, F)$ or from secondary cultures of neonatal nerve ( 7 passages). These Schwann cells had a flattened appearance. MTs were abundant and were widely distributed within these Schwann cells, but few extended from the pericentrin-positive dots (Fig. 1C,D). This MT pattern was observed in all of the sciatic nerve Schwann cells $(>200)$ examined in these in vitro experiments.

\section{Organization of MTs in myelinating Schwann cells}

A detailed description of the organization of MTs in myelinating Schwann cells of teased nerve fibers from sciatic nerves has been published previously (Kidd et al., 1994). A brief description is provided here for comparison with other Schwann cell phenotypes. MTs are numerous in Schwann cell perinuclear cytoplasm and in the cytoplasmic channels that extend along the outer margin of the myelin internode (Fig. 24). Most MTs are oriented parallel to the long axis of the internode. MTs in these cells do not radiate from obvious MT organizing centers (MTOCs) in perinuclear or internodal Schwann cell cytoplasm. To investigate the location of MT minus ends and nucleating sites, Schwann cell MTs were reversibly depolymerized in vivo using colchicine treatment. By 12 and 24 hr after colchicine treatment, numerous short 

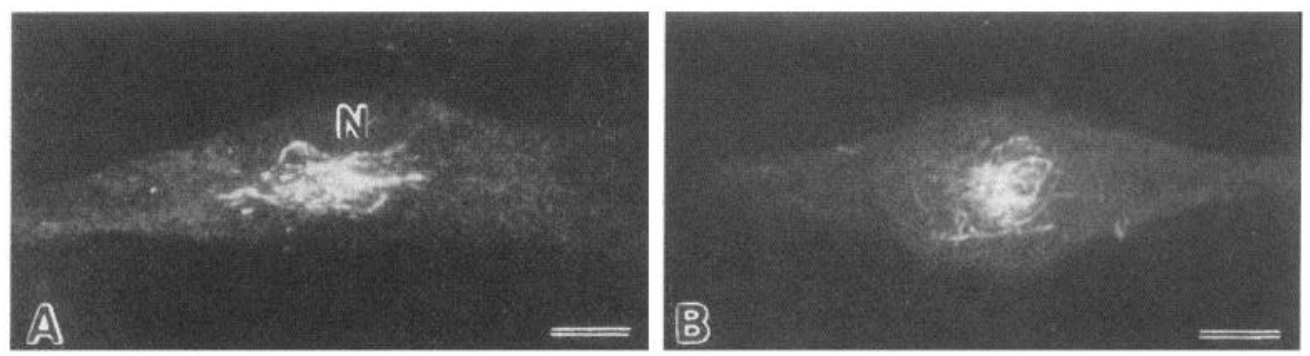

Figure 1. Distribution of MTs and centrosomes in a Schwann cell maintained in vitro. $A-D$, Schwann cells from neonatal dorsal root ganglion primary cultures have a bipolar shape, and MTs radiate from the perinuclear region $(A$, $B)$. Double labeling $(C, D)$ indicates that MTs $(C)$ extend from around the pericentrin-stained centrosome $(D, a r-$ rowhead). $E, F$, Schwann cells isolated from adult sciatic nerve have a flattened appearance. Most MTs $(E)$ in these cells are not attached to the centrosome $(F$, arrowhead); $N$, nucleus. Scale bars, 10 $\mu \mathrm{m}$.
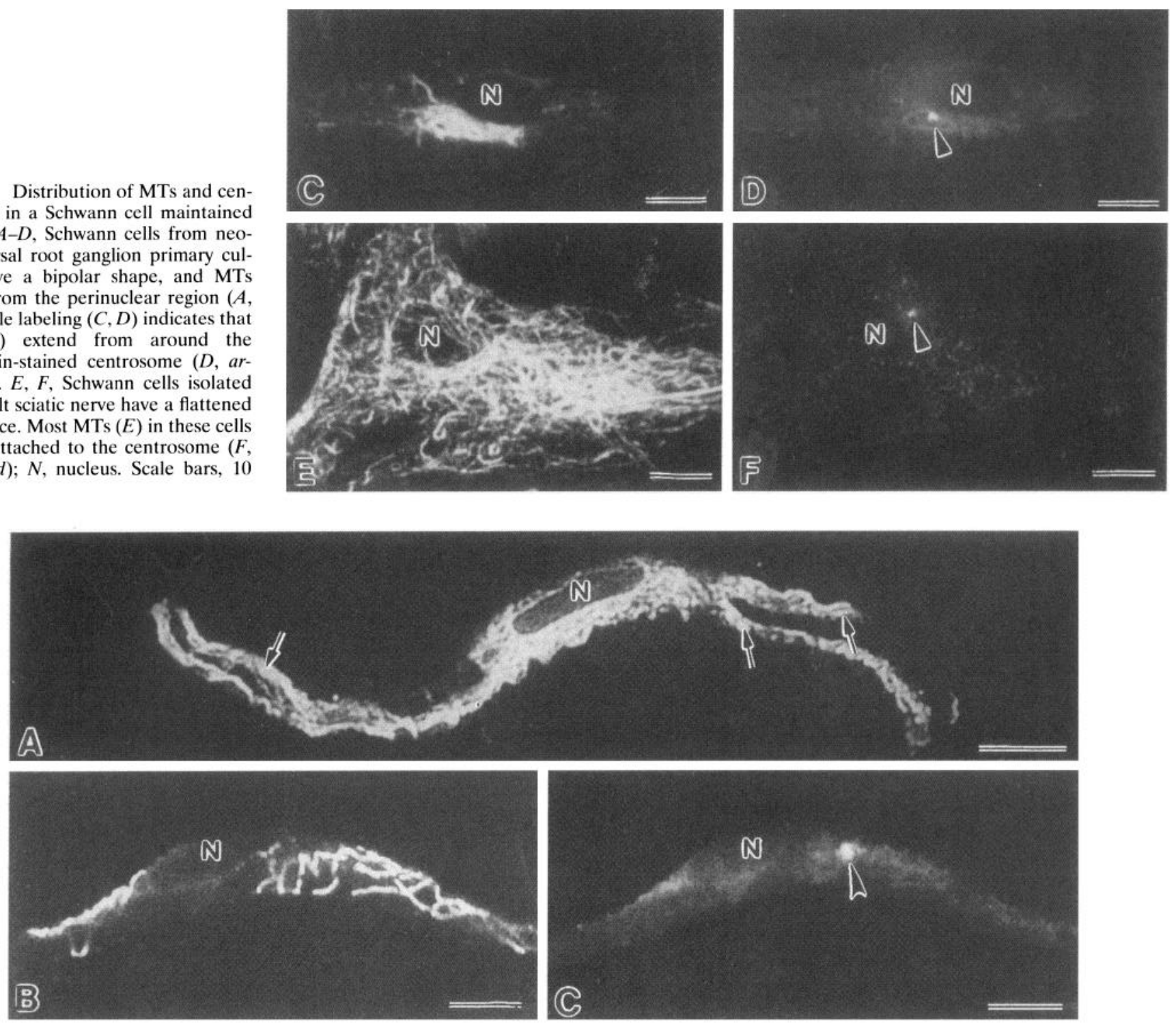

Figure 2. MT distribution in myelinating Schwann cells. In Schwann cells of myelinating fibers $(A)$, MTs are abundant in perinuclear cytoplasm $(N)$ and in channels of cytoplasm that extend along the external surface of the myelin internode $(A$,arrows $)$. After colchicine treatment, MTs repolymerize from multiple sites within the perinuclear cytoplasm $(B)$; MTs are not associated with the centrosome ( $C$, arrowhead) during repolymerization; $N$, nucleus. Scale bars, $10 \mu \mathrm{m}$.

repolymerizing MTs were scattered throughout the Schwann cell perinuclear cytoplasm (Fig. 2B). These perinuclear MTs were dispersed randomly. Asters of MTs and MT organizing elements were not present (Fig. 2B, Table 1). In confocal images double labeled for acetylated $\alpha$-tubulin and pericentrin, few if any MTs in myelinating Schwann cells were associated with the centrosome (Fig. 2B,C). Repolymerizing MTs were not observed at other sites along the internode (Table 1). In contrast to myelinating Schwann cells, repolymerizing MTs in perineurial cells and fibroblasts from the same tissue consistently radiated from a pericentrin-positive centrosome (Kidd et al., 1994). Similar results also were obtained using the MT-depolymerizing drug nocodazole (Kidd et al., 1994).

\section{Organization of MT during Wallerian degeneration}

To investigate whether Schwann cells alter their MT organization and distribution in response to axonal injury, Schwann cells in 
Table 1. Percentage of myelinating Schwann cells with MTOCs in nonlesioned and degenerating nerves from 35-d-old rats

\begin{tabular}{|c|c|c|c|c|c|}
\hline & $\begin{array}{l}\text { No obvious M'I } \\
\text { asters }(\%)\end{array}$ & $\begin{array}{l}\text { Single } \\
\text { perinuclear MT } \\
\text { aster }(\%)\end{array}$ & $\begin{array}{l}\text { Multiple } \\
\text { perinuclear MT } \\
\text { asters }(\%)\end{array}$ & $\begin{array}{l}\text { Nonperinuclear } \\
\text { MT asters also } \\
\text { observed (\%) }\end{array}$ & $\begin{array}{l}\text { Number of } \\
\text { fibers }(n)\end{array}$ \\
\hline Unlesioned sciatic & 100 & 0 & 0 & 0 & 6.3 \\
\hline $24 \mathrm{hr}$ postlesion & 41 & 43 & 16 & 6 & 78 \\
\hline $48 \mathrm{hr}$ postlesion & 18 & 36 & 46 & 29 & 72 \\
\hline $72 \mathrm{hr}$ postlesion & 9 & 29 & 62 & 54 & 68 \\
\hline
\end{tabular}

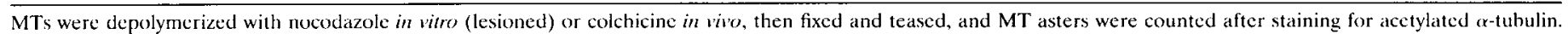
"In some fibers, internodal MT asters may have been missed because of unavoidable nonuniform staining of fiber bundles.

teased nerve fiber preparations were examined at various times after sciatic nerve transection. In these experiments, immunolabeling for $\mathrm{P}_{o}$, protein and transmission-mode confocal microscopy indicated that myelin breakdown followed the expected course of Wallerian degeneration. Initial segmentation of the compact myelin sheath into myelin ovoids occurred by $12 \mathrm{hr}$ after transection. Progressive segmentation of myelin into smaller ovoids and myelin breakdown continued until little myelin remained at $4 \mathrm{~d}$ after transection. This pattern of myelin ovoid formation also occurred after colchicine treatment (see below). Acetylated $\alpha$-tubulinpositive MTs remained numerous in the Schwann cell cytoplasm that surrounded the myelin internode at all stages of degeneration. MTs were retained in the external cytoplasmic channels in long ovoids, but as degeneration progressed and ovoids became smaller, MTs also appeared in the Schwann cell cytoplasm between ovoids.

Some nerves were pretreated with colchicine before transection to determine the location of MT minus ends and nuclcating sites in degenerating internodes. Compared with nontransected, colchicine-treated nerves, MT repolymerization patterns were strikingly different in Schwann cells from transected nerves. By 12 hr after nerve transection, MT asters were detected in the Schwann cell perinuclear cytoplasm. In many Schwann cells, a prominent MTOC was observed (Fig. $3 A-C$ ), and double labeling for pericentrin indicated that the MTOC contained the centrosome (Fig. 3D). Other Schwann cells had multiple perinuclear MTOCs (Fig. 3E); one contained the centrosome, whereas the others exhibited no pericentrin staining. Large bundles of repolymerizing MTs also were observed in most Schwann cells from transected nerves (Fig. $3 E$ ). Similar MT bundles were never observed in nontransected myelinated fibers. Regenerating MTs with no obvious association to MT asters and bundles were also present. As described in detail below for nocodazole-treated tissues, repolymerizing MTs initially ( $12 \mathrm{hr}$ after transection) were restricted to the perinuclear cytoplasm, but at later time points $(24,36$, and $48 \mathrm{hr})$, asters and bundles of repolymerizing MTs were observed at progressively greater distances from the perinuclear region, primarily between degenerating myelin ovoids (Fig. $3 F$ ).

Although colchicine treatment was a useful means of depolymerizing MTs in vivo, colchicine binding to tubulin is essentially irreversible (Dustin, 1984). If the perinuclear cytoplasm is a major site of tubulin synthesis, MT recovery may occur more rapidly there as the colchicine-bound tubulin pool is diluted with newly synthesized unbound tubulin. To avoid this complication, nerve segments were treated with nocodazole, which binds reversibly to tubulin (Hugon et al., 1987). Because this drug diffuses poorly in vivo (Kidd et al., 1994), segments of rat sciatic nerve were exposed to nocodazole and allowed to degenerate in vitro. Myelin ovoid formation proceeded at the same rate as in vivo, both in the presence or absence of nocodazole, although myelin removal was not extensive. Patterns of MT repolymerization closely resembled those observed after colchicine treatment. As indicated in Table 1, at $24 \mathrm{hr}$ in vitro $59 \%$ of Schwann cells had one or more MT asters in the perinuclear region, and MT bundles were common in such cells (Fig. 3G,H). Where multiple MT asters were observed, only one contained the pericentrin-positive centrosome (Fig. $3 G, H$ ). At later time points (36-72 hr), MT asters were observed more frequently in the perinuclear region (Table 1), and Schwann cells with multiple MTOCs became common. As degeneration progressed, MTs were detected beyond the perinuclear region in an increasing number of fibers (Table 1) and were observed at progressively greater distances along the internode. Double labeling for myelin with $\mathrm{P}_{0}$ antibodies or wheat germ agglutinin indicated that most of these M'l's were located between ovoids (see also Fig. $4 E, H$ ), and they frequently formed MT asters (Table 1) and bundles.

To investigate whether other Schwann cell organelles segregated with the newly formed periovoidal MT asters and bundles, teased fibers were immunostained for MTs and the lysosomal marker cathepsin D, or for cathepsin $D$ and the endosomal marker endolyn-78 (Croze et al., 1989). In nontransected nerves, small dots of cathepsin $\mathrm{D}$ staining were distributed evenly in perinuclear and internodal cytoplasm (Fig. 4A,B). Endolyn-78 staining was distributed similarly in slightly larger particles (data not shown). Forty-eight hours after transection, lysosomal and endosomal staining was concentrated between myelin ovoids (Fig. $4 C, D)$ and in perinuclear cytoplasm. Double-labeling studies with acetylated $\alpha$-tubulin and cathepsin $\mathrm{D}$ after colchicine or nocodazole (Fig. 4E,H) treatments indicated that most Schwann cell lysosomes were associated with the MT asters and MT bundles that were located between myelin ovoids. These observations indicate that the MT rearrangement that occurs during Wallerian degeneration segregates degradative organelles to cytoplasm between myelin ovoids. Although Schwann cell lysosomes are likely to help degrade myelin, early stages of ovoid formation and myclin degeneration occur after colchicine treatment when few MTs are present in Schwann cell cytoplasm.

By $4 \mathrm{~d}$ after axotomy, Schwann cells entered a mitotic phase. Double labeling for DNA (propidium jodide) and MTs indicate that most internodal MTs depolymerize at metaphase and that perinuclear MTs are associated with mitotic spindles (data not shown).

\section{DISCUSSION}

The present study establishes that axons regulate the arrangement of Schwann cell MTs. As summarized in Figure 5, an integral part of this regulation influences the number and location of MT- 

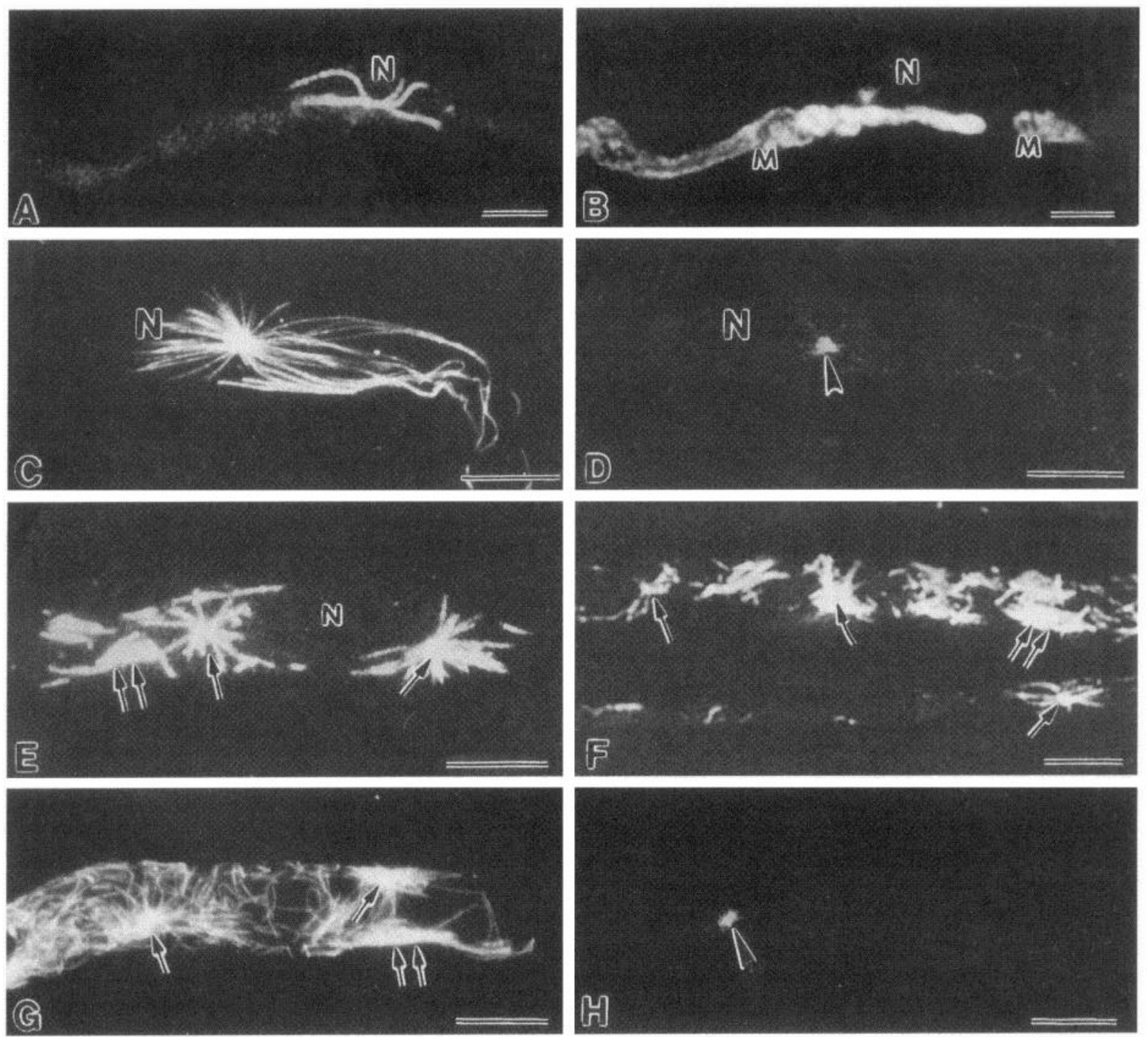

Figure 3. Axonal transection changes the organization of Schwann cell MTs. $A-D$, At $24 \mathrm{hr}$ after transection, MT asters $(A, C)$ are common in perinuclear cytoplasm of degenerating myelin $(M)$ internodes ( $B$ shows double labeling for $\mathrm{P}_{\mathrm{o}}$ protein). These MTOCs $(C)$ contain the centrosome $(D$, arrowhead, pericentrin staining). $E-H$, At $48 \mathrm{hr}$ after transection, multiple MT asters appear in the perinuclear cytoplasm $(E, G$, single arrows $)$ and along the myelin internode $(F)$, primarily between ovoids. Double labeling $(G, H)$ indicates that the centrosome $(H$, arrowhead) is present in only one aster. MT bundles $(E, F, G$, double arrows) are also prominent. $A-F$, Colchicine pretreated in vivo; $G, H$, nocodazole treated in vitro: $N$, nucleus. Scale bars, $10 \mu \mathrm{m}$.

nucleating sites and the location of MT minus ends. Recent studies have demonstrated that MTs are required for translocation of $P_{o}, M A G$, and laminin to surface membranes of myelinating Schwann cells (Trapp et al., 1995). The dynamic rearrangement of Schwann cell MTs during early stages of Wallerian degeneration described in the present study indicates that Schwann cells actively participate in myelin internode degradation. Studies in which MTs were depolymerized with nocodazole suggest that molecules inducing MTOC and MT bundle formation during Wallerian degeneration are translocated from the perinuclear cytoplasm to regions of myelin ovoid formation. Because MTs are not associated with MTOCs in myelinating Schwann cells, MTOC formation during Wallerian degeneration must entail either de novo transcription or de novo activation of molecules that form and regulate MTOCs.

\section{Organization of MTs during Schwann cell development}

The results of this study indicate that Schwann cells rearrange MT networks by changing the location and/or mechanisms of MT nucleation. As neonatal Schwann cells migrate away from dorsal root ganglion explant cultures, their MTs are nucleated from a single site that is associated with the centrosome. Many migrating cell types position the centrosome (MTOC) between the nucleus and the cell exterior and orient MTs toward the direction of locomotion and lamellipod formation (Euteneuer and Schliwa, 1992). Our studies indicate that a similar arrangement occurs in migrating Schwann cells. Schwann cells isolated from adult sciatic nerves and neonatal Schwann cells that were expanded by cholera toxin had different MT arrangements when maintained in vitro. MTs were dispersed throughout the cytoplasm of these nonmigratory cells and were not associated with the centrosome. Although more extensive studies are required to identify the variables that influence Schwann cell MT organization in vitro, our studies indicate that the MT network of Schwann cells maintained in the absence of axons can be dynamically regulated by environmental influences.

The size and three-dimensional configuration of the myelin inter- 

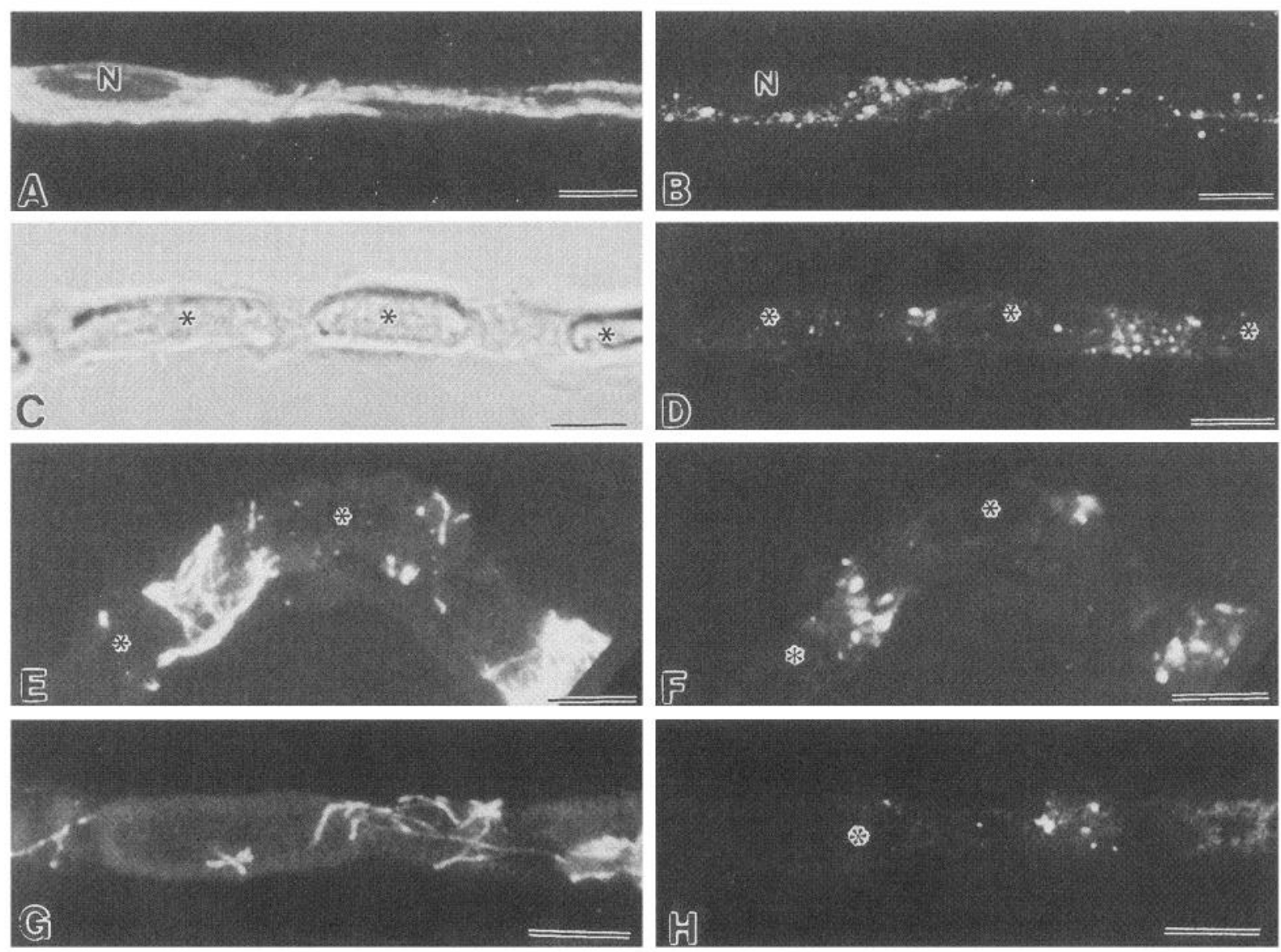

Figure 4. Nerve transection redistributes lysosomes in Schwann cells of myelinated fibers. $A, B$, Lysosomes ( $B$, cathepsin D staining) are widely distributed in the perinuclear and MT-rich $(A)$ cytoplasmic channels at the outer margin of the myelin internode; $N$, nucleus. $C, H$, As myelin ovoids (asterisks) form after nerve transection $(C$, transmitted-light image), lysosomes $(D, F, H)$ become redistributed with MTs $(E, G)$ in the cytoplasm between ovoids. Scale bars, $10 \mu \mathrm{m}$.

node impose special demands on Schwann cell MT networks. MTs in perinuclear cytoplasm organize synthetic organelles and initiate MTbased transport pathways (Kidd et al., 1994; Trapp et al., 1995). As part of their myelinating phenotype, Schwann cells disperse MT minus ends in perinuclear cytoplasm. One consequence of this MT arrangement is the dispersal of the Golgi apparatus, which is tethered to the MT minus ends. Because a large Golgi complex is required for myelin protein synthesis, its association with a single MTOC would be physically impossible. The dispersed arrangement of MTs in myelinating Schwann cells likely establishes transport pathways from the perinuclear cytoplasm to sites along the internode, but seems ill-suited for the site-specific protein targeting described in other polarized epithelial cells (Bre et al., 1987; Achler et al., 1989).

Our MT depolymerization studies indicate that all Schwann cell MTs are generated initially in Schwann cell perinuclear cytoplasm and that this MT nucleation occurs from multiple sites. At the earliest time points at which short, repolymerizing MTs could be identified in Schwann cell perinuclear cytoplasm, neither MT aster formation nor association of MTs with the centrosome was apparent. If myelinating Schwann cell MTs nucleate at a single MTOC, disconnect, and then disperse, as described in neurons (Yu et al., 1993), they must do this so fast that MT-MTOC associations cannot be imaged by confocal microscopy or electron microscopy (G. Kidd, unpublished data). We found no evidence of MT-nucleating struc- tures along the myelin internode or of spontaneous MT selfassembly. Instead, the data indicate that all MT nucleation occurs in the perinuclear cytoplasm of myelinating Schwann cells and that stable MT units are transported out along the internode, perhaps similar to MTs in axons and dendrites (Baas and Ahmad, 1992). MTs located at the outer perimeter of the myelin internode share another property with dendrites, namely, they have a mixed polarity (Kidd et al., 1994). Schwann cells and dendrites may share mechanisms for transporting MTs of mixed polarity or for rotating MTs $180^{\circ}$, because there are no peripheral MT-nucleating sites in either cell (Yu et al., 1993; Kidd et al., 1994). Many functions have been proposed for MT networks with mixed polarity (Baas et al., 1989; Black and Baas, 1989); among those most relevânt to myelinating Schwann cells may be the MT minus end-directed transport and subcellular compartmentation of ribosomes and MBP mRNA (Kidd et al., 1994; Trapp et al., 1995).

\section{Axotomy induces multiple MTOCs in myelinating Schwann cells}

Axonal transection initiates a process of myelin degradation, Schwann cell dedifferentiation, and Schwann cell division that includes a rapid and dramatic reduction in the transcription of myelin protein genes (Politis et al., 1982; Lemke and Chao, 1988; Trapp et al., 1988; Yao et al., 1990; Poduslo and Windebank, 1995). Results of the present study establish that axonal degener- 


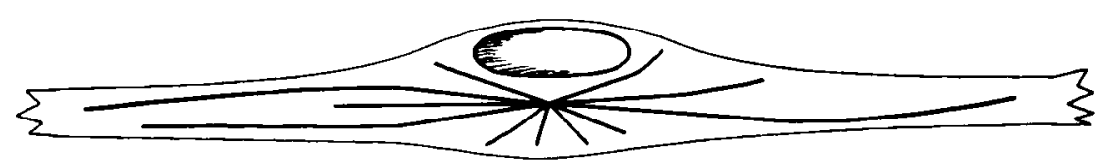

A

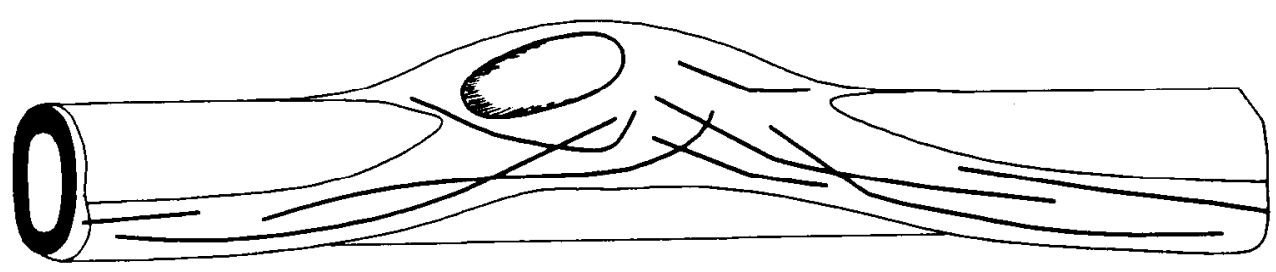

B

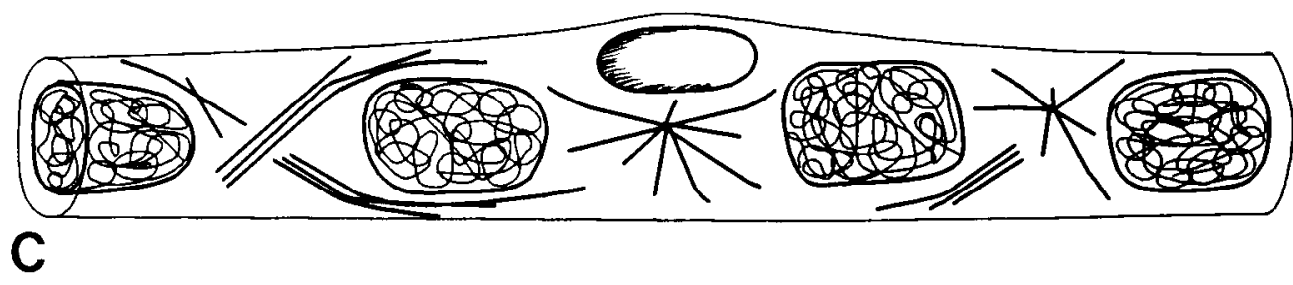

Figure 5. Schwann cell MT changes that accompany axonal contact and axonal degeneration. In Schwann cells without axonal contact $(A)$, MTs radiate from the centrosome. In Schwann cells of myelinated fibers $(B)$, MTs are dispersed in perinuclear cytoplasm. In degenerating internodes $(C)$, the Schwann cell centrosome is re-established as an MTOC, and multiple MTOC and MT bundles form along the myelin internode. ation also causes a dramatic change in the distribution of MTs in myelinating Schwann cells. These distributions are not observed in either neonatal or myelinating Schwann cells. Most obvious are the MTOCs and MT bundles that form between the myelin ovoids during early stages of Wallerian degeneration. The formation of multiple noncentrosomal MTOCs has been reported in other cells (Spiegelman et al., 1979; Dustin, 1984), although the nature of the MT organizing material is not known. The gradual and progressive appearance of these MT organizing elements along the degenerating internode with time after transection suggests that axonal injury induces the active transport of MT-nucleating material from the perinuclear region and promotes transcription of these molecules. Formation of these multiple MTOCs is a transient phenomenon that lasts for 3-4 d. During this time, Schwann cells of degenerating internodes undergo mitosis and all MTs depolymerize, except for those associated with mitotic spindle formation.

A major difference between the central and peripheral nervous system (PNS) is the ability of nerves in the PNS to regenerate. The regenerative capabilities of PNS axons are attributable primarily to properties of the Schwann cell. After peripheral nerve transection, nerve degeneration occurs rapidly at sites distal to the injury (Stoll et al., 1989; Griffin and Hoffman, 1992). The rapid removal of degenerating myelin eliminates myelin molecules that can inhibit neurite outgrowth (Caroni and Schwab, 1988; McKerracher et al., 1994; Mukhopadhyay et al., 1994). As the myelin debris is removed, Schwann cells divide and form continuous columns that serve as substrates for nerve regeneration. The results of the present study establish that Schwann cells of myelinating fibers play an active role in the earliest stages of Wallerian degeneration by rearranging their cytoskeleton. As part of this rearrangement, lysosomes and endosomes become concentrated at the MTOCs between each myelin ovoid. Lysosomal enzymes may help fragment myelin into small ovoids and facilitate its removal by macrophages. Schwann cells also salvage and store lipids during Wallerian degeneration and then reutilize them for remyelination (Rawlins et al., 1972; Boyles et al., 1989; Goodrum et al., 1995). The redistribution of endosomes and their association with the MTOC hetween each degenerating ovoid may facilitate endosomal cycling events that are essential for lipid reutilization. The molecule or molecules responsible for multiple MTOC formation during Wallerian degeneration are unknown. One perinuclear MTOC was associated with the centrosome, whereas all others were not stained by the pericentrin antibody. $\gamma$-Tubulin, another putative MT-nucleating molecule (GuethHallonet et al., 1993), colocalized only with the centrosome in normal and degenerating nerves (G. Kidd, unpublished observations). Degenerating myelin internodes may provide a unique opportunity to identify novel MT-nucleating material.

\section{Axonal regulation of Schwann cell phenotype}

Although the molecular events that govern axonal regulation of Schwann cell phenotype are unknown, many well characterized aspects involve activation or repression of gene transcription (Quarles, 1984; Jessen et al., 1987; Lemke and Chao, 1988; Trapp et al., 1988; Leblanc and Poduslo, 1990). Because the myelinating phenotype of Schwann cells is initiated by physical contact with appropriate axons (Aguayo et al., 1976; Weinberg and Spencer, 1976; Spencer et al., 1981), it is likely that ligand-receptor interactions activate kinases or other second-messenger systems and Schwann cell transcriptional factors. Recent studies have implicated the zinc finger transcription factor, Krox-20, as the transcriptional activator of the $\mathrm{P}_{\mathrm{o}}$ and MBP genes (Topliko et al., 1994). The myelinating signal that axons provide to Schwann cells must inactivate centrosomal nucleating material and activate materials that disperse MT minus ends. Whether this occurs by transcription or by post-translational modifications of MTnucleating material remains to be determined. 
It had been widely accepted that maintenance of the myelinating phenotype of Schwann cells required continued axonal contact (for review, see Heath et al., 1991; Kidd et al., 1992). This idea was challenged by the discovery of axons that are surrounded by two myelin sheaths (Heath, 1982; Kidd and Heath, 1988). Such an arrangement occurs when a Schwann cell extends along the axonal surface and displaces an existing myelin internode. The new Schwann cell then forms another internode and "double myelination" occurs. When the outer sheath in this arrangement is totally separated from the axon, it survives destruction of the inner axon (Kidd and Heath, 1991; Kidd et al., 1992), demonstrating that axonal contact is not necessary for myelin maintenance. Outer myelin sheaths that are not totally displaced from the axon, however, undergo Wallerian degeneration. These studies establish that myelin maintenance does not require axonal contact. Furthermore, they indicate that myelin breakdown during Wallerian degeneration is caused by a positive signal from degenerating axons, rather than from loss of a trophic axonal signal. Although the precise nature of this signal is unclear, it inactivates myelin protein genes (Lemke and Chao, 1988; Trapp et al., 1988; Leblanc and Poduslo, 1990) and induces multiple MTOCs. Recent studies investigating Wallerian degeneration in the C57B1/6 mouse, which harbors a gene defect that delays Wallerian degeneration (Lyon et al., 1993), indicate that activation of axonal calcium is an essential part of the axonal signal that induces Wallerian degeneration (George et al., 1995). Our studies support the possibility that degenerating axons signal transcription of new MTnucleating material. This is a testable hypothesis that could provide valuable insight into mechanisms of Schwann cell gene transcription and MT biology.

\section{REFERENCES}

Achler C, Filmer D, Merte C, Drenckhahn D (1989) Role of microtubules in polarized delivery of apical membrane proteins to the brush border of the intestinal epithelium. J Cell Biol 109:179-189.

Aguayo AJ, Epps J, Charron L, Bray GM (1976) Multipotentiality of Schwann cells in cross anastomosed and grafted myelinated and unmyelinated nerves: quantitative microscopy and radioautography. Rrain Res 104:1-20.

Ariyasu RG, Ellisman MH (1987) The distribution of $\left(\mathrm{Na}^{+}+\mathrm{K}^{+}\right)$ATPase is continuous along the axolemma of unensheathed axons from spinal roots of "dystrophic" mice. J Neurocytol 16:239-248.

Baas PW, Ahmad FJ (1992) The plus ends of stable microtubules are the exclusive nucleating structures for microtubules in the axon. J Cell Biol 116:1231-1241.

Baas PW, Black MM, Banker GA (1989) Changes in microtubule polarity orientation during the development of hippocampal neurons in culture. J Cell Biol 109:3085-3094.

Black MM, Baas PW (1989) The basis of polarity in neurons. Trends Neurosci 12:211-214.

Boyles JK, Zoeliner CD, Anderson LJ, Kosik LM, Pitas RE, Weisgraber KH, Hui DY, Mahley RW, Gebicke-Haerter PJ, Ignatious MJ, Shooter EM (1989) A role for apolipoprotein E, apolipoprotein A-I, and low density lipoprotein receptors in cholesterol transport during regeneration and remyclination of the rat sciatic nerve. J Clin Invest 83:1015-1031.

Bre M-H, Kreis TE, Karsenti E (1987) Control of microtubule nucleation and stability in Madin-Darby canine kidney cells: the occurrence of noncentrosomal, stable detyrosinated microtubules. J Cell Biol 105:1283-1296.

Bre M-H, Pepperkok R, Hill AM, Levilliers N, Ansorge W, Stelzer EHK, Karsenti E (1990) Regulation of microtubule dynamics and nucleation during polarization in MDCK II cells. J Cell Biol 111:3013-3021.

Bunge MB, Williams AK, Wood PM (1982) Neuron-Schwann cell interaction in basal lamina formation. Dev Biol 92:449-460.

Caroni P, Schwab ME (1988) Two membrane protein fractions from rat central myelin with inhibitory properties for neurite growth and fibroblast spreading. J Cell Biol 106:1281-1288.
Croze E, Ivanov IE, Kreibich G, Adesnik M, Sabatini DD, Rosenfeld MG (1989) Endolyn-78, a membrane glycoprotein present in morphologically diverse components of the endosomal and lysosomal compartments: implications for lysosome biogenesis. J Cell Biol 108:1597-1613.

Doxsey SJ, Stein D, Evans P, Calaraco PD, Kirshner M (1994) Pericentrin, a highly conserved centrosome protein involved in microtubule organization. Cell 76:639-650.

Dustin P (1984) Microtubules. Berlin: Springer.

Euteneuer U, Schliwa M (1992) Mechanism of centrosome positioning during the wound response in BSC-1 cells. J Cell Biol 116:1157-1166.

George EB, Glass JD, Griffin JW (1995) Axotomy-induced axonal degeneration is mediated by calcium influx through ion-specific channels. J Neurosci 15:6445-6452.

Goodrum JF, Bouldin TW, Zhang SH, Maeda N, Popko B (1995) Nerve regeneration and cholesterol reutilization occur in the absence of apolipoproteins $\mathrm{E}$ and $\mathrm{A}-\mathrm{I}$ in mice. J Neurochem 64:408-416.

Griffin JW, Hoffman PN (1992) Degeneration and regeneration in the peripheral nervous system. In: Peripheral neuropathy (Dyck PJ, Thomas PK, Griffin JW, Low PA, Poduslo J, eds), pp 361-376. Philadelphia: Saunders.

Gueth-Hallonet C, Antony C, Aghion J, Santa-Maria A, Lajoie-Mazenc I, Wright M, Maro B (1993) $\gamma$-Tubulin is present in acentriolar MTOCs during early mouse devclopment. J Cell Sci 157-166.

Heath JW (1982) Double myelination of axons in the sympathetic nervous system. J Neurocytol 11:249-262.

Heath JW, Kidd GJ, Trapp BD, Dunkley PR (1991) Myelin maintenance by Schwann cells in the absence of axons. Neurosci Lett 128:277-280.

Hugon JS, Bennett G, Pothier P, Ngoma Z (1987) Loss of microtubules and alteration of glycoprotein migration in organ cultures of mouse intestine exposed to nocodazole or colchicine. Cell Tissue Res 248:653-662.

Jessen KR, Mirsky R (1984) Non-myelin-forming Schwann cells coexpress surface proteins and intermediate filaments not found in myelinforming cells: a study of Ran-2, A5E3 antigen and glial fibrillary acidic protein. J Neurocytol 13:923-934.

Jessen KR, Mirsky R, Morgan L (1987) Myelinated, but not unmyelinated, axons reversibly down-regulate N-CAM in Schwann cells. J Neurocytol 16:681-688.

Kidd GJ, Heath JW (1988) Double myelination of axons in the sympathetic nervous system of the mouse. I. Ultrastructural features and distribution. J Neurocytol 17:245-261.

Kidd GJ, Heath JW (1991) Myelin sheath survival following axonal degeneration in doubly myelinated nerve fibers. J Neurosci 11:4003-4014.

Kidd GJ, Andrews SB, Trapp BD (1994) Organization of microtubules in myelinating Schwann cells. J Neurocylul 23:801-810.

Kidd GJ, Heath JW, Trapp BD, Dunkley PR (1992) Myelin sheath survival following guanethidine-induced axonal degeneration. J Cell Biol 116:395-404.

Kreis TE (1990) Role of microtubules in the organization of the Golgi apparatus. Cell Motil Cytoskeleton 15:67-70.

Leblanc AC, Poduslo JF (1990) Axonal modulation of myelin gene expression in the peripheral nerve. Proc Natl Acad Sci USA 26:317-326.

Lemke G, Chao M (1988) Axons regulate Schwann cell expression of the major myelin and NGF receptor genes. Development 102:499-504.

Lyon MF, Ogunkolade BW, Brown MC, Atherton DJ, Perry VH (1993) A gene affecting Wallerian nerve degeneration maps distally on mouse chromosome 4. Proc Natl Acad Sci USA 90:9717-9720.

Martini R, Schachner M (1986) Immunoelectron microscopic localization of neural cell adhesion molecules (L1, N-CAM, and MAG) and their shared carbohydrate epitope and myelin basic protein in developing sciatic nerve. J Cell Biol 103:2439-2448.

Matteoni R, Kreis TE (1987) Translocation and clustering of endosomes and lysosomes depends on microtubules. J Cell Biol 105:1253-1265.

McKerracher L, David S, Jackson DL, Kottis V, Dunn RJ, Braun PE (1994) Identification of myelin-associated glycoprotein as a major myelin-derived inhibitor of neurite growth. Neuron 13:805-811.

Mezei C (1993) Myelination in the peripheral nerve during development. In: Peripheral neuropathy (Dyck PJ, Thomas PK, Griffin JW, Low PA, Poduslo J, eds), pp 267-281. Philadelphia: Saunders.

Mirsky R, Winter J, Abney ER, Pruss RM, Gavrilovic J, Raff MC (1980) Myelin-specific proteins and glycolipids in rat Schwann cells and oligodendrocytes in culture. J Cell Binl 84:483-494.

Mostov K, Apodaca G, Aroeti B, Okamoto C (1992) Plasma membrane protein sorting in polarized epithelial cells. J Cell Biol 116:577-583. 
Mukhopadhyay G, Doherty P, Walsh FS, Crocker PR, Filbin MT (1994) A novel role for myelin-associated glycoprotein as an inhibitor of axonal regeneration. Neuron 13:757-767.

Parton RG, Dotti CG, Bacallao R, Kurtz I, Simons K, Prydz K (1991) $\mathrm{pH}$-induced microtubule-dependent redistribution of late endosomes in neuronal and epithelial cells. J Cell Biol 113:261-274.

Peters A, Palay SL, Webster HD (1991) The fine structure of the nervous system: neurons and their supporting cells. New York: Oxford UP.

Piperno G, Fuller MT (1985) Monoclonal antibodies specific for an acetylated form of $\alpha$-tubulin recognize the antigen in cilia and flagella from a variety of organisms. J Cell Biol 101:2085-2094.

Piperno G, LeDizet M, Chang X (1987) Microtubules containing acetylated $\alpha$-tubulin in mammalian cells in culture. J Cell Biol 104:289-302.

Poduslo JF, Windebank AJ (1995) Differentiation-specific regulation of Schwann cell expression of the major myelin glycoprotein. Proc Natl Acad Sci USA 82:5987-5991.

Poduslo JF, Berg CT, Dyck PJ (1984) Schwann cell expression of a major myelin glycoprotein in the absence of myclin asscmbly. Proc Natl Acad Sci USA 81:1864-1866.

Politis MJ, Sternberger NH, Ederle K, Spencer PS (1982) Studies on the control of myelinogenesis. IV. Neuronal induction of Schwann cell myelin-specific protein synthesis during nerve fiber regeneration. J Neurosci 2:1252-1266.

Quarles RH (1984) Myelin-associated glycoprotein in development and disease. Dev Neurosci 6:285-303.

Rawlins FA, Villegas GM, Hedley-White ET, Uzman BG (1972) Fine structural localization of cholesterol- $1,2{ }^{3} \mathrm{H}$ in degenerating and regenerating mouse sciatic nerve. J Cell Biol 52:615-625.

Rodriguez-Boulan E, Nelson WJ (1989) Morphogenesis of the polarized epithelial cell phenotype. Science 245:718-725.

Rutkowski L, Needham L, Frayer K, Carson D, McKhann G, Tennekoon G (1990) Evidence that secondary Schwann cells in culture maintain their differentiated phenotype. J Neurochem 54:1895-1904.

Seilheimer B, Schachner M (1987) Regulation of neural cell adhesion molecule expression on cultured mouse Schwann cells by nerve growth factor. EMBO J 6:1611-1616.

Simons K, Wandinger-Ness A (1990) Polarized sorting in epithelia. Cell 62:207-210.

Spencer PS, Politis MJ, Pellegrino RG, Weinberg HJ (1981) Control of Schwann cell behavior during nerve degeneration and regeneration. In: Posttraumatic peripheral nerve regeneration: experimental basis and clinical implications (Gorio A, Millesi H, Mingrino S, eds), pp 411-426. New York: Raven.
Spiegelman BM, Lopata MA, Kirschner MW (1979) Multiple sites for the initiation of microtubule assembly in mammalian cells. Cell $16: 239-252$

Stoll G, Griffin JW, Li CY, Trapp BD (1989) Wallerian degencration in the peripheral nervous system: participation of both Schwann cells and macrophages in myelin degradation. J Neurocytol 18:671-683.

Taniuchi M, Clark HB, Johnson Jr EM (1986) Induction of nerve growth factor receptors in Schwann cells after axotomy. Proc Natl Acad Sci USA 83:4093-4098.

Thomas PK, Barthold C-H, Ochoa J (1993) Microscopic anatomy of the peripheral nervous system. In: Peripheral neuropathy (Dyck PJ, Thomas PK, Griffin JW, Low PA, Poduslo JF, eds), pp 28-98. Philadelphia: Saunders.

Thyberg J, Moskalewski S (1985) Microtubules and the organization of the Golgi complex. Exp Cell Res 159:1-16.

Topliko P, Schneider-Maunoury S, Levi G, Baron-Van Evercooren A Chennoufi ABY, Seitanidou T, Babinet C, Charnay P (1994) Krox-20 controls myclination in the peripheral nervous system. Nature 371:796-799.

Trapp BD, Hauer P, Lemke G (1988) Axonal regulation of myelin protein mRNA levels in actively myelinating Schwann cells. J Neurosci 8:3515-3521.

Trapp BD, Itoyama Y, Sternberger NH, Quarles RH, Webster HD (1981) Immunocytochemical localization of $P o$ protein in Golgi complex membranes and myelin of developing rat Schwann cells. J Cell Biol 90:1-6.

Trapp BD, Kidd GJ, Hauer PE, Mulrenin E, Haney C, Andrews SB (1995) Polarization of myelinating Schwann cell surface membranes: role of microtubules and the trans-Golgi network. J Neurosci 15:1797-1807.

Weinberg HJ, Spencer PS (1976) Studies on the control of myelinogenesis. II. Evidence for neuronal regulation of myelin production. Brain Res 113:363-378.

Winter J, Mirsky R, Kadlubowski M (1982) Immunocytochemical study of the appearance of $\mathrm{P} 2$ in developing rat peripheral nerve: comparison with other myelin components. J Neurocytol 11:351-362.

Yao J, Harvath L, Gilbert DL, Colton CA (1990) Chemotaxis by a CNS macrophage, the microglia. J Neurosci Res 27:36-42.

Yasuda H, Dyck PJ (1987) Abnormalities of endoneurial microvessels and sural nerve pathology in diabetic neuropathy. Neurology 37:20-28.

Yu W, Centonze VE, Ahmad FJ, Baas PW (1993) Microtubule nucleation and release from the neuronal centrosome. J Cell Biol 122: $349-359$. 